\title{
Metazoan plankton and the structure of the plankton community in the stratified North Sea
}

\author{
H. G. Fransz ${ }^{1, *}$, S. R. Gonzalez ${ }^{1}$, S. F. Steeneken ${ }^{2}$ \\ 'Netherlands Institute for Sea Research, PO Box 59, 1790 AB Den Burg, The Netherlands \\ ${ }^{2}$ Department of Marine Biology of the University of Groningen, PO Box 14, 9750 AA Haren, The Netherlands
}

\begin{abstract}
The hypothesis of size-differential control of phytoplankton was tested by sampling stations on a transect from the Dogger Bank to the Shetland Isles in the North Sea on cruises in March/April and July/August 1994. On this transect light limitation was expected in spring, and an increase in nutrient limitation was expected from north to south in summer. The Shetland area, where nutrient levels and primary production rates were highest in summer, did not show the correspondingly higher relative abundances of large algae which would have been predicted by the hypothesis. The question addressed in this study is how the highly abundant zooplankton in the stratified North Sea in summer affect the structure of the plankton community of interacting algae, heterotrophic protists and metazoans. Variations in zooplankton species distributions revealed 4 latitudinal subregions. The Calanus finmarchicus population in the central North Sea reproduced in March. In August, reproduction rates were highest in the 2 northernmost regions. Carbon specific ingestion based on in vitro egg production rates led to an estimate of $10.4 \%$ for these stations in summer. It was concluded that the stratified central and northern North Sea can vary with latitude in zooplankton species composition, population structure and vertical distribution. In summer, adjacent subregions can differ widely in vertical distribution of $C$. finmarchicus biomass. High copepod abundance and grazing rates can promote the dominance of small algae by causing mortality of large algae and heterotrophic protists (grazers of small algae). During summer in the North Sea, egg production rates indicated an increased grazing activity of $C$. finmarchicus towards the north. This could have obscured the negative effect of decreasing nutrient limitation on the dominance of small algae predicted by the hypothesis of size-differential control of phytoplankton.
\end{abstract}

KEY WORDS: Mesozooplankton - Calanus finmarchicus - Biomass - Egg production - Plankton community structure $\cdot$ Size-differential control $\cdot$ North Sea

\section{INTRODUCTION}

The zooplankton communities of the summer stratified offshore North Sea waters, north of the Dogger Bank, are dominated by species whose distribution centre is in the North Atlantic Ocean (Fransz et al. 1991, Williams et al. 1993, Krause et al. 1995). Acrossshelf transport (Backhaus et al. 1994, Slagstad \& Tande 1996) between the Atlantic Ocean and the central gyre of the North Sea may lead to zooplankton enrichment on the shelf in spring In addition, it has been argued that the North Sea is richer in zooplankton than the

\footnotetext{
•E-mail: fransz@nioz.nl
}

open ocean due to a better exploitation of the diatom spring bloom (Colebrook 1979, 1984).

The question addressed in this study is how the highly abundant zooplankton found in the stratified North Sea in summer affect the structure of the plankton community of interacting algae, heterotrophic protists and metazoans. Riegman et al. (1993) postulated that size-differential grazing control of phytoplankton determines the structure of plankton communities. Their hypothesis distinguished asymptotic equilibrium states of pelagic systems, which depended on the level of the factor limiting algal growth rate. Low levels of light or nutrients result in systems dominated by small algae, microzooplankton and carnivorous mesozooplankton. High levels of nutrients and adequate light 
stimulate new production, which leads to higher abundances of the less competitive larger algae (i.e. those not eaten by microzooplankton) and their predators, the herbivorous copepods.

To test this hypothesis, a transect was sampled between Dogger Bank and the Shetland Isles in the spring and summer of 1994. On this transect light limitation was expected in spring, and an increase in nutrient limitation was expected from north to south in summer. Size-specific biomass and productivity of algae, bacteria, and microzooplankton, as well as the biomass, abundance and reproductivity of mesozooplankton were studied simultaneously to observe and interpret latitudinal trends. In addition, copepod eggs and nauplii were sampled because they can be numerous and indicative of reproductive rates. The results concerning algae and heterotrophic protists were presented in separate papers (Riegman \& Noordeloos 1998, Riegman et al. 1998, Kuipers \& Witte 1999), but should be regarded as concomitant information for the interpretation of zooplankton variation and its effects on the plankton community.

In agreement with the predictions of Riegman et al. (1993), the cessation of light limitation in spring in the Dogger Bank area turned the dominance from small to large algae, presumably due to size-dependent differences in grazing pressure because the small algae grew faster than the larger ones (Riegman et al. 1998). In summer, however, the Shetland area, where nutrient levels and primary production rates were highest, did not show the correspondingly higher relative abundances of large algae which would have been predicted by the model of Riegman et al. (1993) (Riegman \& Noordeloos 1998). In this paper, results about the metazoan plankton in the size class 50 to $2000 \mu \mathrm{m}$ (mesozooplankton plus copepod eggs and nauplii) are presented to elucidate their possible role in the size control of phytoplankton.

\section{MATERIAL AND METHODS}

Linear transects (Fig. 1) were sampled at fixed stations between March 28 and April 15 (RV 'Pelagia'), and between July 25 and August 12 (RV 'Zirfaea') in 1994. There were 7 main stations (H) spaced equidistantly between Dogger Bank and the $61^{\circ} \mathrm{N}$ parallel at about 60 nautical mile intervals, and additional stations 10 miles west (W) or east (O) of these positions. In both periods zooplankton was sampled near a mooring station (M) south of Dogger Bank, and during the summer some intermediate additional stations $(\mathrm{N})$ were sampled.

The zooplankton were collected by successive hauls with 2 nets at various times during the day. For meso-

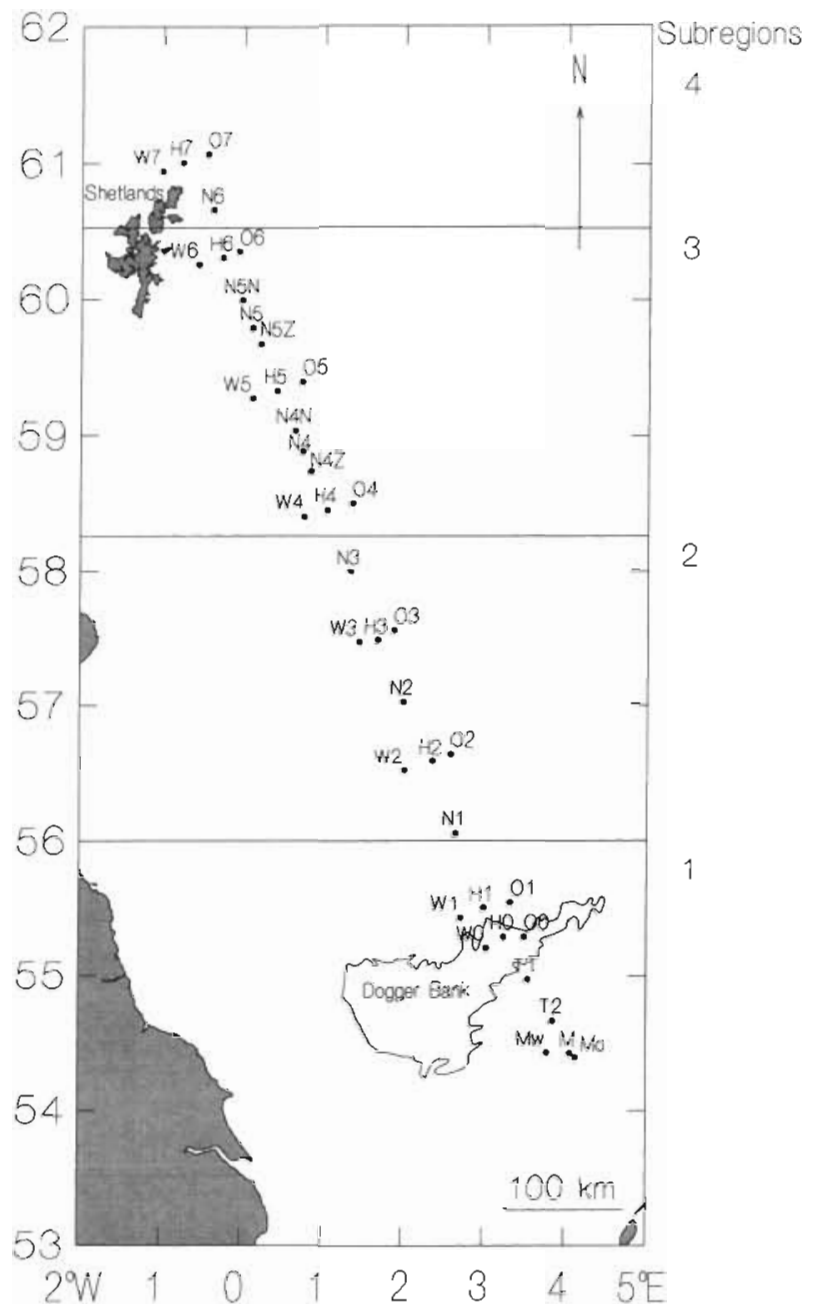

Fig. 1. Sampling stations on the transect from the Dogger Bank area to the Shetland Isles in the North Sea as grouped in latitudinal subregions

zooplankton a WP-2 net with $0.25 \mathrm{~m}^{2}$ aperture and $200 \mu \mathrm{m}$ meshed nylon gauze was used and for smaller organisms such as copepod eggs and nauplii a $2.5 \mathrm{~m}$ long cylindrical nylon net with $50 \mu \mathrm{m}$ mesh size and $0.07 \mathrm{~m}^{2}$ aperture (Daan 1987, Fransz 1988). Both nets were fitted with flowmeters to estimate volumes filtered, and a messenger-operated opening/closing device. During spring, vertical hauis were made from bottom to surface to obtain depth-integrated samples for the whole mixed water column. During the summer cruise, hauls were differentiated for a deep part below the bottom of the thermocline, and an upper part including the thermocline zone and the upper mixed layer.

The samples were fixed in $4 \%$ borax-buffered formaldehyde and sorted within 1 yr. Individuals of a size retained by a $1 \mathrm{~mm}$ sieve were identified and counted in large aliquots from the WP-2 net, contain- 
ing 50 to 200 individuals. The smaller individuals were sorted in the same quantity in small aliquots from both nets, while eggs and nauplii were counted mainly from the smaller net. In general the highest density estimate of either net was used. Copepods were counted to species and developmental stage level in length classes of 20 to $100 \mu \mathrm{m}$ depending on maximum length. Most other species were pooled in larger taxonomic groups.

Ash-free dry weight (AFDW) was estimated as the unit of biomass. Specific log-linear relationships were adopted from literature to convert length to AFDW, assuming that AFDW is $90 \%$ of total dry weight (Omori 1978, Fransz \& van Arkel 1980, Mizdalski 1988, Diel 1991) and correcting for the use of fixed or frozen material (Omori 1978, Williams \& Robins 1982) (Table 1). Published weights and lengths were combined for regression analysis. If only stage and weight were given, the corresponding mean length in our data was assumed. For the other taxa, AFDW was estimated as a mean value per organism from an estimate of mean volume, assuming an AFDW/volume ratio of $10 \%$ (Wiebe et al. 1975).

Separate vertical hauls were made during daylight with the WP-2 net to collect adult females and subadult copepodite stages of the calanoid copepads Calanus finmarchicus and Temora longicornis to study egg production rates. In spring these samples were taken from the whole water column, in summer from the upper layers above the lower boundary of the thermocline. According to Fransz et al. (1989), 15 active adult females were incubated at ambient mixed layer temperature in covered 51 containers, filled with $50 \mu \mathrm{m}$ mesh filtered sea water without in situ eggs, and stored in a air-conditioned laboratory on board. The number of newly produced eggs in the containers was counted after $24 \mathrm{~h}$ and divided by the number of females. The mortality of the females was always lower than $0.5 \%$. No measures were taken to prevent egg cannibalism

\section{RESULTS}

\section{Latitudinal distribution of biomass and species structure}

The species distribution showed 4 discernible latitudinal zones, which differed also to some extent in the developmental structure of the 2 numerically most dominant species Calanus finmarchicus (Fig. 2) and Oithona similis (Fig. 3) The stations were grouped according to these subregions (Fig. 1). Details about water masses and current systems of the subregions can be found in Turrell (1992), Backhaus et al. (1994) and Krause et al. (1995). Per season and depth layer, the number of sam-
Table 1 Ash-free dry weight-length relationships in North Sea zooplankton species. $W=a L^{b}$ in $\mu$ g AFDW with length $L$ in $\mathrm{mm}$ (cephalothorax length in copepodids)

\begin{tabular}{|c|c|c|c|}
\hline Species & a & $b$ & Source \\
\hline \multicolumn{4}{|l|}{ Copepodis } \\
\hline Calanus finmarchicus & 13.2 & 3.26 & 1 \\
\hline Calanus nauplii & 17.4 & 2.27 & 2 \\
\hline Calanus helgolandicus & 19.5 & 2.69 & 3 \\
\hline Pseudocalanus elongatus & 19.0 & 2.73 & 2 \\
\hline Pseudocalanus nauplii & 17.4 & 2.27 & 2 \\
\hline Paracalanus parvus & 19.0 & 2.73 & 2 \\
\hline Microcalanus sp. & 19.0 & 2.73 & 2 \\
\hline Temora longicornis & 30.5 & 3.06 & 2 \\
\hline Temora nauplii & 9.5 & 2.17 & 2 \\
\hline Centropages hamatus & 17.9 & 2.45 & 2 \\
\hline Centropages nauplii & 14.9 & 2.24 & 2 \\
\hline Centropages typicus & 14.4 & 2.50 & 4 \\
\hline Metridia lucens & 13.8 & 3.91 & 5 \\
\hline Acartia sp. & 15.5 & 2.97 & 2 \\
\hline Acartia nauplii & 89.0 & 3.21 & 2 \\
\hline Oithona similis & 6.5 & 2.16 & 6 \\
\hline Oithona nauplii & 17.0 & 2.71 & 6 \\
\hline Oncaea sp. & 35.2 & 3.11 & 4 \\
\hline Euterpina acutifrons & 11.2 & 2.10 & 4 \\
\hline Microsetella norvegica & 5.1 & 2.12 & 4 \\
\hline Other copepodid species & 17.9 & 2.45 & 2 \\
\hline Other copepod nauplii & 14.9 & 2.24 & 2 \\
\hline \multicolumn{4}{|l|}{ Larvaceans } \\
\hline Oikopleura dioica & 17.8 & 2.49 & 7 \\
\hline \multicolumn{4}{|l|}{ Chaetognaths } \\
\hline Sagitta sp. & 0.06 & 2.94 & 4 \\
\hline \multicolumn{4}{|l|}{ Hydrozoans } \\
\hline Phyalidium hemisphaericum & 5.44 & 1.48 & 8 \\
\hline Eucheilota maculata & 63.8 & 1.02 & 8 \\
\hline Helgicirrha schulzei & 0.87 & 3.06 & 8 \\
\hline Aequorea sp. & 0.87 & 3.06 & 8 \\
\hline Other sp. & 5.44 & 1.48 & 8 \\
\hline \multicolumn{4}{|l|}{ Scyphozoans } \\
\hline Aurelia aurita & 11.4 & 2.28 & 8 \\
\hline Cyanea sp. & 0.87 & 3.06 & 8 \\
\hline Chrysara hyoscella & 0.87 & 3.06 & 8 \\
\hline \multicolumn{4}{|l|}{ Fish larvae } \\
\hline Clupea harengus & 0.06 & 3.75 & 8 \\
\hline Sprattus sprattus & 0.06 & 3.75 & 8 \\
\hline Hyperoplus lanceolatus & 0.51 & 2.86 & 8 \\
\hline Pomatoschystus sp. & 2.44 & 2.54 & 8 \\
\hline Merlangius merlangus & 2.48 & 2.71 & 8 \\
\hline Trisopterus luscus & 0.91 & 3.25 & 8 \\
\hline Callionymus reticulatus & 17.3 & 2.01 & 8 \\
\hline Trachinus vipera & 3.88 & 2.71 & 8 \\
\hline Pleuronectes platessa & 0.92 & 3.24 & 8 \\
\hline Limanda limánda & 0.92 & 3.24 & 8 \\
\hline Buglossidium luteum & 8.83 & 2.14 & 8 \\
\hline Trachurus trachurus & 2.56 & 2.85 & 8 \\
\hline Rhinonemus cimbrius & 1.59 & 2.98 & 8 \\
\hline Scomber scombrus & 1.59 & 2.98 & 8 \\
\hline \multicolumn{4}{|c|}{ Sources } \\
\hline \multicolumn{4}{|c|}{ 1. Fransz (1980), Williams \& Lindley (1980) } \\
\hline \multicolumn{4}{|c|}{ 2: Klein Breteler et al. (1982) } \\
\hline \multicolumn{4}{|c|}{ 3: Williams \& Robins (1982), Bottrell \& Robins (1984) } \\
\hline \multicolumn{4}{|c|}{ 4: Nassogne (1972) } \\
\hline \multicolumn{4}{|c|}{ 5: Gronvik \& Hopkins (1984), Conover \& Huntley (1991) } \\
\hline \multicolumn{4}{|c|}{ 6: Sabatini \& Kirrboe (1994) } \\
\hline \multicolumn{4}{|c|}{ 7: Paffenhöfer (1976) } \\
\hline \multicolumn{4}{|c|}{ 8: Fransz et al. (1978), Seip \& Ottema (1981) } \\
\hline
\end{tabular}



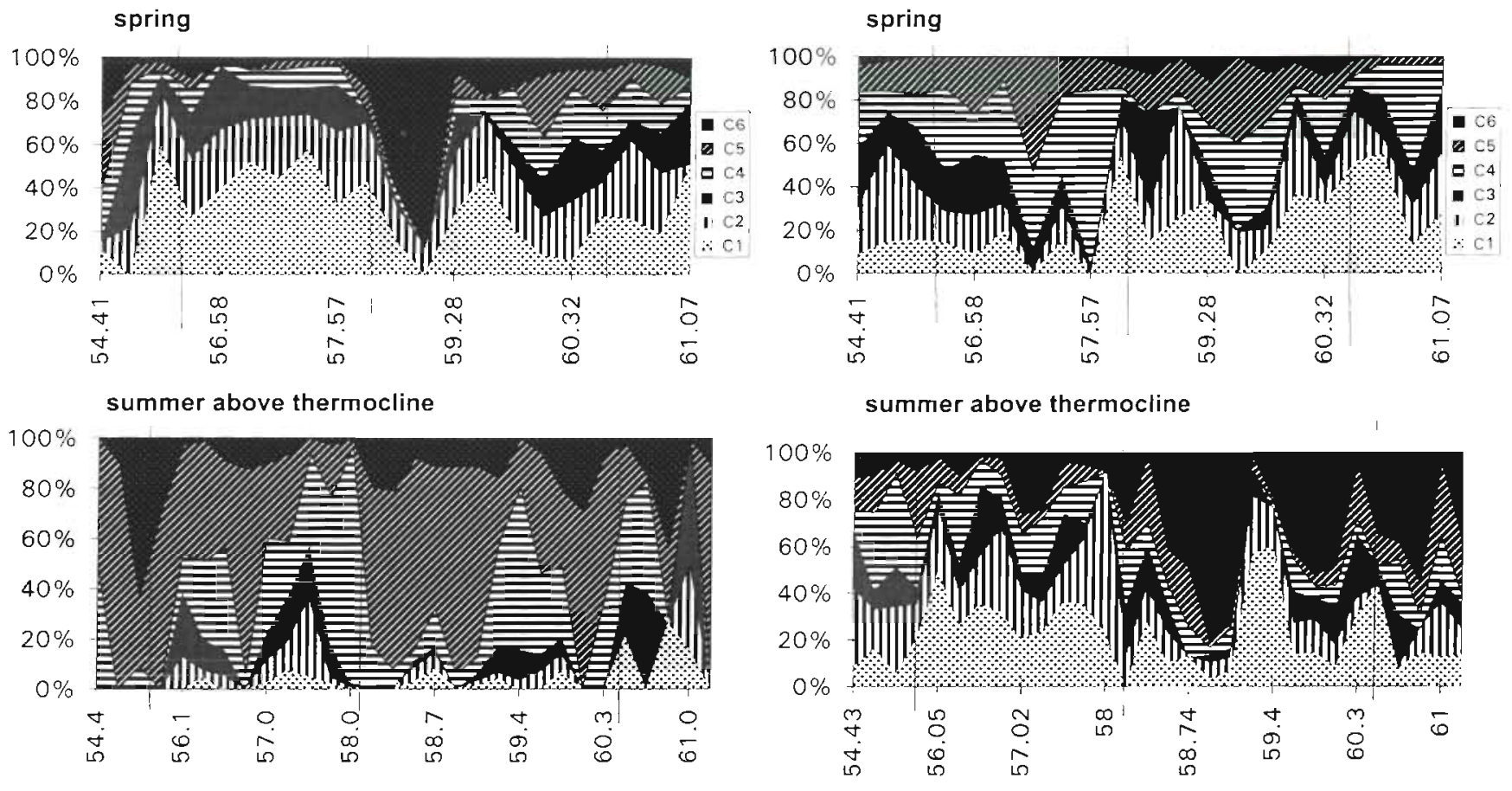

summer below thermocline

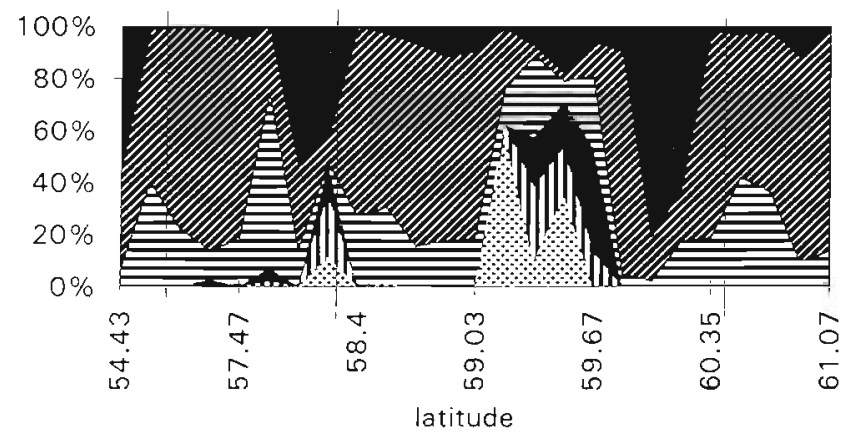

Fig. 2. Calanus finmarchicus. Latitudinal distribution of copepodite stages with indications of the subregions

pled stations, mean time of sampling and hydrographical data are given for these subregions in Table $2 ;$ mean biomass of metazoan plankton taxa in Table $3 ;$ and the abundance of developmental stages of Calanus and Oithona in Table 4 . The 4 latitudinal zones differed in the following aspects

(1) At the lowest latitude $\left(54^{\circ}\right.$ to $\left.56^{\circ} \mathrm{N}\right)$, the Dogger Bank area, the community was dominated in summer by Temora longicornis and other more or less neritic species, such as Paracalanus parvus and Pseudocalanus elongatus. Calanus finmarchicus had its lowest summer abundance here, but in early spring it formed $35 \%$ of total biomass. C. finmarchicus copepodids younger thar $\mathrm{C} 4$ were not found here during summer and were scarce in spring. This may indicate a

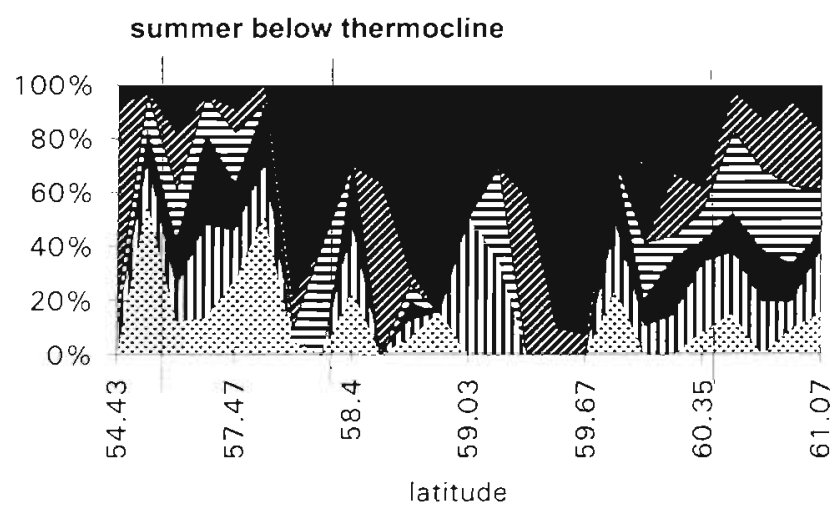

Fig. 3. Oithona simulis. Latitudinal distribution of copepodite stages with indications of the subregions

reduced reproductive success or increased mortality of the young stages during late spring and summer.

(2) The central North Sea $\left(56^{\circ}\right.$ to $\left.58^{\circ} \mathrm{N}\right)$ was characterized by relatively high summer abundances of Oithona similis, Centropages typicus, benthic larvae and amphipods. Calanus finmarchicus was also very abundant in summer, even in the subthermocline layer. It was more abundant in spring here than in the other areas. Young copepodite stages of this species were dominant in spring and occurred also in summer with highest abundances in the upper mixed layer.

(3) The area from $58^{\circ}$ to $60.5^{\circ} \mathrm{N}$ is influenced by eastward extensions of inflows from the Atlantic Ocean such as the Fair Isle current, the Dooley current and their more eastern equivalents (Krause et al. 1995). 
Table 2. Partitioning in subregions according to season and depth layer with number of stations (n), mean sampling time in hours GMT, mean lowest depth in $\mathrm{m}$, mean depth-integrated temperature in ${ }^{\circ} \mathrm{C}$, and chlorophyll a in $\mu \mathrm{g} \mathrm{l}^{-1}$

\begin{tabular}{|lccccc|}
\hline $\begin{array}{l}\text { Sub- } \\
\text { region }\end{array}$ & $\mathrm{n}$ & GMT & Depth & Temp. & $\begin{array}{c}\text { Chloro- } \\
\text { phyll }\end{array}$ \\
\hline Spring & & & & & \\
1 & 11 & $12: 00$ & 38 & 5.6 & 1.60 \\
2 & 6 & $10: 00$ & 79 & 5.6 & 0.76 \\
3 & 9 & $11: 00$ & 126 & 6.3 & 0.34 \\
4 & 3 & $09: 00$ & 117 & 7.6 & 0.42 \\
Summer, upper layer & & & \\
1 & 4 & $09: 00$ & 25 & 18.4 & 0.66 \\
2 & 9 & $11: 00$ & 53 & 12.6 & 0.66 \\
3 & 13 & $11: 00$ & 57 & 12.4 & 0.67 \\
4 & 4 & $09: 00$ & 34 & 14.0 & 1.75 \\
Summer, deep layer & & & \\
1 & 1 & $08: 00$ & 35 & 9.4 & 1.45 \\
2 & 7 & $11: 00$ & 79 & 6.1 & 0.26 \\
3 & 13 & $12: 00$ & 120 & 7.0 & 0.08 \\
4 & 4 & $09: 00$ & 105 & 9.9 & 0.06 \\
\hline
\end{tabular}

These currents also include inputs of mixed Scottish Coastal Water. In summer Calanus finmarchicus and Oithona similis were dominant in the surface layers, while their biomass was low below the thermocline. The biomass of $C$. finmarchicus in spring was lower than in the more southern areas of the Dogger Bank and the central North Sea, with a high dominance of adults. During summer, the transect between $59^{\circ}$ and $60^{\circ} \mathrm{N}$ showed a differentiation in the vertical distribution of $C$. finmarchicus copepodids. In general, juveniles younger than $\mathrm{C} 4$ were a minority in the layer below the thermocline, but here they formed more than $50 \%$ of the total number of copepodids in the deep layer and only $20 \%$ in the upper layer, where the older stages dominated. $O$. similis, which had a rather homogeneous stage distribution (mainly subadults) in the other areas, showed a relatively large summer contribution of adults, particularly in the deep layer. This may all indicate that the spring reproduction of copepods had started later or had been less successful in this subregion

(4) North of $60.5^{\circ} \mathrm{N}$ Atlantic Slope Water prevails. In summer the surface layer showed the highest observed biomass of Calanus helgolandicus, Pseudocalanus elongatus and Oithona similis. Probably Atlantic Ocean surface flows in combination with the Continental Slope Jet (Backhaus et al. 1994) brought southern species such as C. helgolandicus into this region. In the deep layer a relatively high biomass of Metridia lucens was found and a deep maximum of $C$. finmarchicus, which may be endemic here or brought from the north by counter currents. Developmental distributions were similar to those in the Central North Sea Water.

The mean total biomass of the stations in all subregions increased from $28 \mathrm{mg} A F D W \mathrm{~m}^{-3}$ in spring to $161 \mathrm{mg}$ in the upper layers and $73 \mathrm{mg}$ in the subther-

Table 3. Mean AFDW in $\mathrm{mg} \mathrm{m}^{-3}$ of zooplankton species and groups in different subregions, seasons and depth layers

\begin{tabular}{|c|c|c|c|c|c|c|c|c|c|c|c|c|}
\hline \multirow[b]{2}{*}{ Subregion: } & \multicolumn{4}{|c|}{ Spring } & \multicolumn{4}{|c|}{ Summer above thermocline } & \multicolumn{4}{|c|}{ Summer below thermocline } \\
\hline & 1 & 2 & 3 & 4 & 1 & 2 & 3 & 4 & 1 & 2 & 3 & 4 \\
\hline Calanus finmarchicus & 13.3 & 18.6 & 7.3 & 2.6 & 5.2 & 111.9 & 156.5 & 44.6 & 1.9 & 85.9 & 18.4 & 81.8 \\
\hline Calanus helgolandicus & 0.0 & 0.0 & 0.2 & 0.4 & 1.7 & 0.6 & 2.0 & 16.1 & 4.5 & 0.0 & 0.9 & 0.8 \\
\hline Pseudocalanus elongatus & 2.4 & 0.6 & 0.3 & 0.4 & 4.4 & 2.7 & 0.9 & 18.7 & 1.4 & 0.6 & 0.0 & 1.5 \\
\hline Paracalanus parvus & 0.1 & 0.1 & 0.1 & 0.0 & 12.9 & 2.5 & 0.2 & 1.6 & 0.7 & 0.3 & 0.0 & 0.0 \\
\hline Microcalanus pusillus & 1.6 & 1.2 & 0.4 & 0.2 & 0.2 & 1.4 & 0.1 & 0.3 & 0.0 & 0.2 & 0.2 & 0.5 \\
\hline Temora longicornis & 5.0 & 0.0 & 0.0 & 0.0 & 21.0 & 0.3 & 0.0 & 1.2 & 3.0 & 0.0 & 0.0 & 0.0 \\
\hline Centropages hamatus & 0.1 & 0.0 & 0.0 & 0.0 & 4.8 & 0.3 & 0.0 & 0.1 & 0.0 & 0.0 & 0.0 & 0.0 \\
\hline Centropages typicus & 0.3 & 0.0 & 0.0 & 0.0 & 2.7 & 3.6 & 0.1 & 0.3 & 0.1 & 0.3 & 0.0 & 0.1 \\
\hline Acartia clausi & 0.1 & 0.0 & 0.0 & 0.0 & 0.4 & 0.4 & 0.0 & 1.4 & 0.0 & 0.0 & 0.0 & 0.0 \\
\hline Metridia lucens & 1.7 & 1.6 & 0.4 & 0.5 & 0.0 & 2.8 & 2.7 & 2.1 & 0.0 & 0.7 & 1.8 & 16.3 \\
\hline Oithona similis & 2.6 & 1.6 & 0.4 & 0.3 & 8.0 & 14.8 & 6.2 & 23.2 & 1.8 & 5.8 & 0.3 & 2.4 \\
\hline Oithona nana & 0.0 & 0.0 & 0.0 & 0.0 & 0.2 & 0.2 & 0.3 & 0.6 & 0.0 & 0.3 & 0.0 & 0.2 \\
\hline Microsetella norvegica & 0.7 & 0.0 & 0.0 & 0.0 & 0.3 & 0.5 & 0.3 & 0.7 & 0.4 & 0.1 & 0.0 & 0.1 \\
\hline Other copepods & 0.0 & 0.0 & 0.0 & 0.1 & 0.8 & 0.6 & 0.0 & 1.0 & 0.0 & 0.0 & 0.0 & 0.0 \\
\hline Larvaceans & 0.3 & 0.1 & 0.1 & 0.1 & 1.1 & 0.1 & 0.0 & 0.0 & 0.2 & 0.0 & 0.0 & 0.0 \\
\hline Benthic larvae & 5.5 & 2.1 & 1.4 & 1.4 & 2.0 & 28.5 & 6.2 & 12.3 & 0.7 & 7.0 & 0.0 & 0.5 \\
\hline Amphipods & 1.0 & 1.1 & 0.1 & 0.0 & 0.0 & 15.3 & 0.1 & 0.0 & 0.0 & 45.9 & 0.2 & 0.0 \\
\hline Euphausids & 0.0 & 0.4 & 0.1 & 34.0 & 0.0 & 2.8 & 0.5 & 0.1 & 0.0 & 0.3 & 1.7 & 0.9 \\
\hline Sagitta sp. & 0.4 & 0.2 & 0.0 & 0.0 & 0.9 & 1.7 & 0.1 & 0.1 & 0.9 & 1.3 & 0.1 & 0.1 \\
\hline Hydrozoa & 0.1 & 0.0 & 0.0 & 0.0 & 8.3 & 0.3 & 0.4 & 1.1 & 1.2 & 0.2 & 0.0 & 0.0 \\
\hline Other zooplankton & 1.7 & 0.7 & 2.1 & 1.2 & 2.5 & 0.3 & 0.2 & 0.4 & 0.3 & 2.7 & 0.0 & 0.1 \\
\hline Total & 36.7 & 28.4 & 13.1 & 41.0 & 77.3 & 192.2 & 176.8 & 125.7 & 17.2 & 153.9 & 23.8 & 105.1 \\
\hline
\end{tabular}


Table 4. Mean depth-integrated abundance of developmental stages in $\mathrm{N} \mathrm{m}^{-3}$ of the 4 subregions during spring and summer for Calanus and Oithona

\begin{tabular}{|c|c|c|c|c|c|c|c|c|}
\hline & \multicolumn{4}{|c|}{ Spring } & \multicolumn{4}{|c|}{ Summer } \\
\hline & 1 & 2 & 3 & 4 & 1 & 2 & 3 & 4 \\
\hline \multicolumn{9}{|c|}{$\begin{array}{l}\text { C. finmarchicus if recognised, smaller stages may partly } \\
\text { be } C \text {. helgolandicus }\end{array}$} \\
\hline Eggs & 1028 & 415 & 303 & 31 & 0 & 41 & 425 & 1749 \\
\hline N1 & 25 & 0 & 0 & 0 & 0 & 0 & 4 & 0 \\
\hline N2 & 261 & 242 & 54 & 13 & 0 & 0 & 22 & 67 \\
\hline N3 & 159 & 59 & 14 & 0 & 0 & 0 & 13 & 7 \\
\hline N4 & 342 & 232 & 28 & 0 & 0 & 0 & 5 & 86 \\
\hline N5 & 141 & 325 & 44 & 15 & 13 & 118 & 7 & 59 \\
\hline N6 & 95 & 235 & 27 & 26 & 0 & 161 & 17 & 229 \\
\hline $\mathrm{C} 1$ & 87 & 271 & 18 & 14 & 0 & 23 & 11 & 16 \\
\hline $\mathrm{C} 2$ & 37 & 150 & 20 & 15 & 0 & 80 & 17 & 9 \\
\hline C3 & 18 & 119 & 13 & 8 & 0 & 115 & 44 & 18 \\
\hline C4 & 15 & 39 & 14 & 8 & 1 & 449 & 218 & 51 \\
\hline $\mathrm{C} 5$ & 19 & 9 & 10 & 6 & 18 & 321 & 309 & 253 \\
\hline C6f & 8 & 10 & 15 & 1 & 5 & 63 & 42 & 34 \\
\hline $\mathrm{C} 6 \mathrm{~m}$ & 5 & 0 & 1 & 1 & 2 & 3 & 5 & 15 \\
\hline \multicolumn{9}{|c|}{$\begin{array}{l}\text { O. similis if recognised, smaller stages may partly be } \\
\text { other species }\end{array}$} \\
\hline Eggs & 3710 & 1405 & 204 & 1041 & 8961 & 3866 & 1980 & 4738 \\
\hline N1 & 173 & 214 & 24 & 0 & 395 & 545 & 308 & 531 \\
\hline N2 & 887 & 924 & 171 & 69 & 1962 & 5232 & 1856 & 1982 \\
\hline N3 & 935 & 690 & 228 & 165 & $409 ?$ & 11118 & 2230 & 2778 \\
\hline N4 & 953 & 422 & 249 & 258 & 4653 & 9931 & 1547 & 2639 \\
\hline N5 & 743 & 256 & 143 & 143 & 3563 & 5006 & 1093 & 1850 \\
\hline N6 & 458 & 253 & 51 & 110 & 1307 & 1381 & 140 & 817 \\
\hline $\mathrm{C} 1$ & 239 & 133 & 134 & 136 & 471 & 4069 & 488 & 486 \\
\hline $\mathrm{C} 2$ & 461 & 142 & 79 & 34 & 729 & 2836 & 201 & 628 \\
\hline C3 & 470 & 229 & 43 & 63 & 413 & 1884 & 126 & 421 \\
\hline $\mathrm{C} 4$ & 319 & 352 & 58 & 61 & 999 & 1200 & 86 & 609 \\
\hline C5 & 275 & 236 & 55 & 10 & 674 & 640 & 124 & 893 \\
\hline C6f & 19 & 1 & 10 & 0 & 230 & 443 & 402 & 972 \\
\hline $\mathrm{C} 6 \mathrm{~m}$ & 6 & 0 & 8 & 0 & 11 & 139 & 83 & 150 \\
\hline
\end{tabular}

mocline layers in summer. Since in most species the carbon content of AFDW ranges between 35 and $55 \%$ (Wiebe et al. 1975, Paffenhöfer 1976, Omori 1978, Uye 1982, Williams \& Robins 1982, Bottrell \& Robins 1984,
Grønvik \& Hopkins 1984, Cataletto \& Umani 1994, Matondka et al. 1995, Lindley et al. 1997), these values

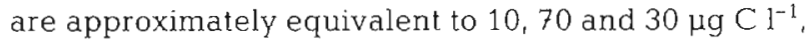
respectively. The contribution of copepods to total metazoan biomass was consistently high, on average $70 \%$ in spring and 80 to $90 \%$ in summer. It was highest below the thermocline in summer. Of the other groups, benthic larvae, amphipods and euphausiids only occasionally formed a major contribution

Because different plankton components and total suspended matter were studied at the sampled stations, it was possible to compare the zooplankton carbon with other POC components in the upper $40 \mathrm{~m}$ of the 4 zooplankton subregions (Table 5). Suspended detritus was estimated by subtracting bacterial, algal and heterotrophic protist carbon from POC and set to zero if this led to negative values.

\section{Egg production and egg/female biomass ratio}

Daily egg production rates for Calanus finmarchicus and Temora longicornis during spring and summer (Fig. 4) ranged between 0 and 30 eggs per female. The reproductive rates varied with season and subregion. For $T$. longicornis egg production was more or less restricted to the Dogger Bank area, where it was highest in spring. For C. finmarchicus it was also high in this area in spring, but almost nil in the more northern regions. In contrast, in July/August $C$. finmarchicus reproduced most actively in the northern sub-regions which had the most oceanic influence. These latitudinal trends for $C$. finmarchicus agree with observations of the in situ egg/female biomass ratios (Fig. 5), where high values in summer were even more restricted to the most northern stations. T. longicornis was too rare north of Dogger Bank to demonstrate its latitudinal trend in in situ reproduction. But distributions for the more common Pseudocalanus elongatus and Oithona

Table 5. Mean concentrations in $\mu \mathrm{g} \mathrm{C}^{-1}$ of POC, detritus and biomass in different size classes of plankton in the upper $40 \mathrm{~m}$ of latitudinal subregions. Data for POC from Kuipers et al. (unpubl.), for bacteria from Vosjan \& van Noort (pers. comm.), for algae from Riegman et al. (1998) and Riegman \& Noordeloos (1998), and for heterotrophic protists from Kuipers \& Witte (1999)

\begin{tabular}{|c|c|c|c|c|c|c|c|}
\hline Subregion & Bacteria & Algae $<5 \mu \mathrm{m}$ & Algae $>5 \mu \mathrm{m}$ & Het. protists & Metazoans & Detritus & $\mathrm{POC}$ \\
\hline \multicolumn{8}{|l|}{ Spring } \\
\hline 1 & - & 12.5 & 125.0 & 2.3 & 16.5 & - & 300 \\
\hline 2 & 16.4 & 10.0 & 25.0 & 2.0 & 12.8 & 66.6 & 120 \\
\hline 3 & 12.9 & 2.5 & 5.0 & 1.2 & 5.9 & 78.4 & 100 \\
\hline 4 & - & 5.0 & 7.5 & 2.3 & 18.5 & - & 100 \\
\hline \multicolumn{8}{|l|}{ Summer } \\
\hline 1 & - & 54.0 & 24.0 & 2.0 & 34.8 & - & 304 \\
\hline 2 & 51.4 & 24.0 & 12.0 & 7.5 & 86.5 & 25.1 & 120 \\
\hline 3 & 58.9 & 36.0 & 18.0 & 10.0 & 79.6 & 0.0 & 102 \\
\hline 4 & 69.4 & 72.0 & 30.0 & 18.0 & 56.6 & 0.0 & 109 \\
\hline
\end{tabular}




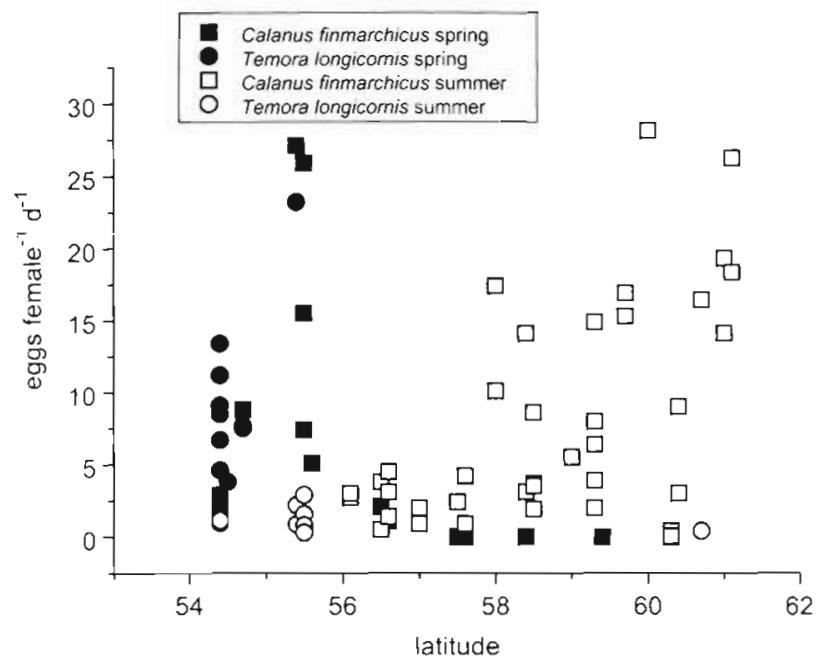

Fig. 4. Latitudinal distribution of in vitro egg production rates

similis (Fig. 5) showed that the trends found for $C$. finmarchicus were rather common for copepods, although $O$. similis had the highest summer activity in subregion 3. Nauplius abundance was related to egg abundance, but for $C$. finmarchicus this abundance was highest in the southern regions in spring (Table 4).

\section{DISCUSSION}

Metazoan carbon stocks as high as shown in Table 5 are not exceptional for the North Sea plankton. Williams \& Lindley (1980) estimated an increase of Calanus finmarchicus between March and mid June 1976 in the Fladen Ground area (subregion 3 in this study) from about 4 to 68 $\mu \mathrm{g} \mathrm{C}^{-1}$ in the upper $100 \mathrm{~m}$. Winter values for the whole water column in 1987-1988

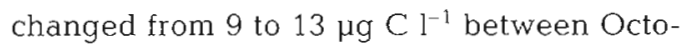
ber and February/March in the Dogger Bank area, and from 2 to $9 \mu \mathrm{g} \mathrm{C} \mathrm{l}^{-1}$ in the northern central North Sea (Hay et al. 1991). In May 1990, Nielsen et al. (1993) found concentrations of up to about $20 \mu \mathrm{g} \mathrm{C}^{-1}$ near the Dogger Bank, mainly comprising Oithona spp. These studies also found that the Dogger Bank area is predominantly populated by small neritic calanoid copepods and Oithona spp., while the zooplankton biomass of more northern waters is dominated by $C$. finmarchicus and $O$. similis. In this study, the carbon ratio of metazoans and their main algal food of larger size varied in March from 0.13 at Dogger Bank to 2.5 near the Shetlands, while it was about 5.5 in August in both central sub- regions and 1.7 at the extreme south and north (Table 5). Shifts in dominance can occur when peaks of algae and zooplankton alternate in a seasonal succession (Colebrook 1979, Fransz \& Gieskes 1984). The central North Sea may be dominated by copepods for the greatest part of the year.

Fransz \& Gonzalez (1991), Hay et al. (1991) and Hay (1995) have presented evidence that copepods grow and reproduce throughout the winter in the North Sea, with lowest egg production rates occurring between November and January. There is a trend of increasing winter reproduction from northwest to southeast. Additionally, the diatom spring bloom starts earlier in the south, which is reflected by the latitudinal distribution of algal biomass abserved in spring (Table 5). Both trends promote the early spring development of copepod populations in the Dogger Bank region. Figs. 4 \& 5 indicate that in early spring egg production rate and egg/female biomass ratio were highest in the Dogger Bank area in all observed species, including Calanus finmarchicus.

A winter spawning population of Calanus finmarchicus in the central North Sea and the presence here in early spring of a large contribution of its juvenile stages (Fig. 2) was not expected. It is known that this species hibernates in deep water and tends to leave the North Sea in November/December, to return by Ekman drift from the Atlantic Ocean from February onwards as older copepodids and adults (Backhaus et al. 1994, Krause et al. 1995, Planque et al. 1997). Can it be that the majority of the juvenile stages in fact belonged to $C$. helgolandicus? Hay et al. (1991) considered (egg laying) C. helgolandicus to be more abun-

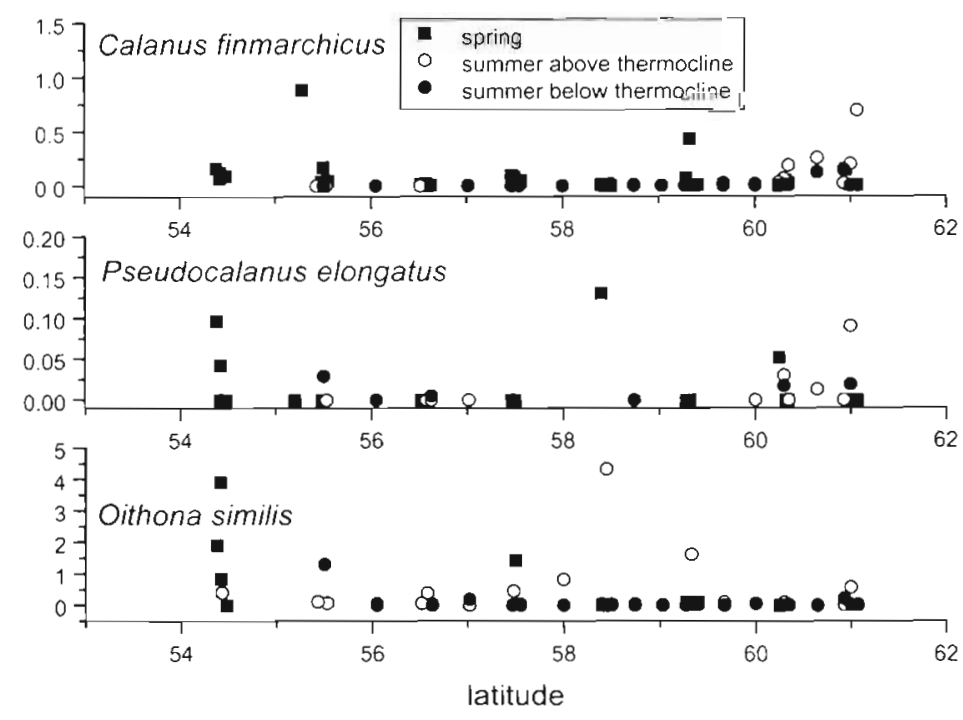

Fig. 5. Latitudinal variation of the in situ egg/female biomass ratio for various copepod species 
dant in the North Sea than. C. finmarchicus during winter, in particular in the more southern part. But CPR data presented by Planque \& Fromentin (1996) suggest a generally higher abundance of $C$. finmarchicus than of C. helgolandicus in March/April in the Dogger Bank area. Because both species are similar in size and appearance, they are easily confused in the sorting routine. Our results, however, do not exclude that $C$. finmarchicus partly remains active in the southern central North Sea during winter and contributes to the local trend of early reproduction and development. Bathmann et al. (1990) observed grazing by C. finmarchicus in late winter in the Norwegian Sea, indicating that this species has more than one option in its overwintering strategy. Overwintering and early spawning in the southern central North Sea in combination with dispersion and wind-driven advection may provide a second source for reinvasion of the northern North Sea.

In the central and northern North Sea copepod densities are low in winter, although some species such as Oithona similis and Paracalanus parvus can survive in larger numbers (Krause et al. 1995). O. similis is very versatile in its diet, which includes small algal cells and heterotrophs, and calanoid fecal pellets (Gonzalez \& Smetacek 1994, Atkinson 1995, Nielsen \& Sabatini 1996, Nakamura \& Turner 1997). In comparison with small calanoid species it can sustain high egg production rates and higher biomass during winter in many temperate seas, when it may utilize dominant small flagellates (Sabatini \& Kiørboe 1994). In spring, Calanus finmarchicus returns from the North Atlantic Ocean. From the onset of the diatom spring bloom in April/May it builds up a high biomass, which lasts until July/August. During summer C. finmarchicus is by far the most dominant grazer of larger algae (Table 3), while it can sustain egg production in summer at low chlorophyll levels by feeding on low densities of heterotrophic aloricate ciliates and dinoflagellates (Ohman \& Runge 1994). Its preference for algal size classes is most likely the $>5 \mu \mathrm{m}$ class (Harris 1996)

In August, the primary production rate north of Dogger Bank appeared to be rather constant at about $1 \mathrm{~g} \mathrm{C}$ $\mathrm{m}^{-2} \mathrm{~d}^{-1}$, increasing to $1.4 \mathrm{~g} \mathrm{C} \mathrm{m}^{-2} \mathrm{~d}^{-1}$ north of $\mathrm{H} 6$ (Riegman \& Noordeloos 1998). The algae <5 $\mu \mathrm{m}$ were grazed upon by protists at a rate closely matching their growth rate, but the larger algae were grazed only moderately by this group (Kuipers \& Witte 1999). Because both algal size classes tended to grow at the same rate (Riegman \& Noordeloos 1998), the mortality rate of the larger algae must have been at least equal to the mortality rate of the smaller ones to prevent an. outbreak of the larger ones. This would require a mortality of the larger algae near the Shetlands of one third (the contribution of the larger algae to algal carbon in
Table 5) of $1.4 \mathrm{~g} \mathrm{C} \mathrm{m}^{-2} \mathrm{~d}^{-1}$, which would amount to about $10 \mu \mathrm{g} \mathrm{C} \mathrm{I}^{-1} \mathrm{~d}^{-1}$ in the upper $40 \mathrm{~m}$. Can herbivory by copepods cause such mortality in August? This may be judged from levels of copepod ingestion indicated by estimated egg production rates.

In incubation experiments, Calanus finmarchicus females produced, on average, about 15 eggs $\mathrm{d}^{-1}$ at the northernmost stations (Fig, 4). The high in situ egg/ female biomass ratio at the northernmost stations (average 0.25 in Fig. 5 for C. finmarchicus), however, corresponds to an in situ egg production rate of about 140 eggs female ${ }^{-1} \mathrm{~d}^{-1}$ (McLaren 1966), suggesting egg production rates in vitro may have been underestimated. Because in vitro egg production rates of $C$. finmarchicus at comparable temperature and food conditions range between 15 and 80 eggs female ${ }^{-1} \mathrm{~d}^{-1}$ (Diel \& Tande 1992, Plourde \& Runge 1993, Hirche et al. 1997), the in situ production rate may be unrealistically high. But the in vitro estimate may be too low due to egg cannibalism, although this was not observed in Temora longicornis in laboratory experiments and in well-fed Calanus marshallae, but was observed in starved C. marshallae (Daan et al. 1988, Peterson 1988). At an egg weight of $0.23 \mu \mathrm{g} \mathrm{C}$ (Runge \& Plourde

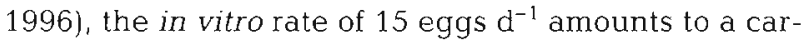
bon specific production rate of $2.6 \% \mathrm{~d}^{-1}$. The gross efficiency of egg production was estimated in the closely related species C. marshallae by Peterson (1988), who found egg production rate was ca $25 \%$ of ingestion rate over a wide range of ingestion rates. If we may apply this to $C$. finmarchicus then, based on the rate of in vitro egg production the carbon specific ingestion rate in August at the northernmost stations was at least $10.4 \% \mathrm{~d}^{-1}$. Because virtually all developmental stages of the dominant species still occurred in August (Table 4), it seems reasonable to assume that the conservative estimate of $10 \%$ daily ingestion also applies as a minimum estimate for the whole $C$. finmarchicus population and the total zooplankton carbon. This would suggest a minimum consumption of about $6 \mu \mathrm{g}$ $\mathrm{C}^{-1} \mathrm{~d}^{-1}$ in the upper $40 \mathrm{~m}$ near the Shetlands (Table 5), enough to explain a substantial part of the mortality of larger algae.

It can be concluded that the stratified central and northern North Sea can vary with latitude in zooplankton species composition, population structure and vertical distribution. This relates to latitudinal trends in the timing of the spring development, the ratio of neritic and oceanic species, and the intensity of exchange with the Atlantic Ocean. In summer, adjacent subregions can differ widely in vertical distribution of Calanus finmarchicus biomass, which stresses the necessity to study the dynamics of this species in the whole water column. High copepod abundance and grazing rates can prevent blooms of large algae and 
can promote the dominance of small algae, because they increase the mortality of large algae. Oithona similis and maybe $C$. finmarchicus can also increase the mortality of heterotrophic protists, which are grazers of small algae. In summer conditions in the North Sea, egg production rates indicated an increased grazing activity of $C$. finmarchicus towards the north, while the abundance of $O$. similis culminated near the Shetlands (Table 4). The corresponding increase of mortality in large algae and ciliates could have obscured the negative effect of decreasing nutrient limitation on the dominance of small algae as predicted by the hypothesis of size-differential control of phytoplankton.

Acknowledgements. We thank the captains and the crews of RV 'Pelagia' and 'Zirfaea' for their skilful assistance at sea, $\mathrm{H}$. van Noort for her assistance with the sorting and enumeration of the zooplankton samples, and Dr G. J Herndl and Dr R. Riegman as well as 4 anonymous referees for critical reading of the manuscript. The cruise program was funded by the Netherlands Geosciences Foundation of NWO. This is NIOZ publication no. 3336

\section{LITERATURE CITED}

Atkinson A (1995) Omnivory and feeding selectivity in five copepod species during spring in the Bellingshausen Sea, Antarctica. ICES J Mar Sci 52:385-397

Backhaus JO, Harms IH, Krause M, Heath MR (1994) An hypothesis concerning the space time succession of Calanus finmarchicus in the northern North Sea. ICES J Mar Sci 51:169-180

Bathmann UV, Noji TT, von Bodungen B (1990) Copepod grazing potential in late winter in the Norwegian Sea-a factor in the control of spring phytoplankton growth? Mar Ecol Prog Ser 60:225-233

Bottrell HH, Robins DB (1984) Seasonal variations in length, dry weight, carbon and nitrogen in Calanus helgolandicus from the Celtic Sea. Mar Ecol Prog Ser 14:259-268

Cataletto B, Umani SF (1994) Seasonal variations in carbon and nitrogen content of Acartia clausi (Copepoda. Calanoida) in the Gulf of Trieste (Northern Adriatic Sea). Hydrobiologia 293:283-288

Colebrook JM (1979) Continuous plankton records: seasonal cycles of phytoplankton and copepods in the North Atlantic Ocean and the North Sea. Mar Biol 51:23-33

Colebrook JM (1984) Continuous plankton records: relationships between species of phytoplankton and zooplankton in the seasonal cycle. Mar Biol 83:313-323

Conover RJ. Huntley M (1991) Copepods in ice-covered seadistribution, adaptations to seasonally limited food, metabolism, growth patterns and life cycle strategies in polar seas. J Mar Syst 2:1-40

Daan R (1987) Impact of egg predation by Noctiluca miliaris on the summer development of copepod populations in the southern North Sea. Mar Ecol Prog Ser 37:9-17

Daan R, Gonzalez SR, Klein Breteler WCM (1988) Cannibalism in omnivorous calanoid copepods. Mar Ecol Prog Ser $47: 45-54$

Diel S (1991) On the life history of dominant copepod species (Calanus finmarchicus, C. glacialis, C. hyperboreus, Metridia longa) in the Fram Strait. Ber Polarforsch 88:1-88

Diel S, Tande K (1992) Does the spawning of Calanus fin- marchicus in high latitudes follow a reproducible pattern? Mar Biol 113:21-31

Fransz HG (1980) Zooplankton development in a patch of juvenile plaice during 26 February-18 March 1980 in the Southern Bight of the North Sea. ICES Comm Meet $1980 /$ L:72

Fransz HG (1988) Vernal abundance, structure and development of nipelagic copepod populations of the eastern Weddell Sed (Antartica). Polar Biol 9:107-114

Fransz HG, Gieskes WWC (1984) The unbalance of phytoplankton and copepods in the North Sea. Rapp PV Réun Cons Int Explor Mer 183:218-225

Fransz HG, Gonzalez SR (1991) Daily egg production of Temora longicornis (Copepoda, calanoida) during winter and early spring in the Marsdiep (southern North Sea). Hydrobiol Bull 25:61-64

Fransz HG, van Arkel WG (1980) Zooplankton activity during and after the phytoplankton spring bloom at the central station in the FLEX box, northern North Sea, with special reference to the calanoid copepod Calanus finmarchicus (Gunn.). 'Meteor' Forsch Ergeb A. 22:113-121

Fransz HG, Ottema $M$, Seip PA (1978) Abundance and growth of fish larvae during the summer decline of copepod populations in Dutch coastal waters of the North Sea and possible interactions with jellyfish and ctenophores. ICES Comm Meet 1978/L:19

Fransz HG, Gonzalez SR, Klein Breteler WCM (1989) Fecundity as a factor controlling the seasonal population cycle in Temora longicornis (Copepoda, Calanoida). In: Ryland JS, Tyler PA (eds) Reproduction, genetics and distributions of marine organisms. Olsen \& Olsen, Fredensborg, p 83-89

Fransz HG, Colebrook JM, Gamble JC, Krause M (1991) The zooplankton in the North Sea. Neth J Sea Res 28:1-52

Gonzalez HE, Smetacek V (1994) The possible role of the cyclopoid copepod Oithona in retarding vertical flux of zooplankton faecal material. Mar Ecol Prog Ser 113: $233-246$

Grenvik S, Hopkins CCE (1984) Ecological investigations of the zooplankton community of Balsfjorden, northern Norway: generation cycle, seasonal vertical distribution, and seasonal variations in body weight and carbon and nitrogen content of the copepod Metridia longa (Lubbock). J Exp Mar Biol Ecol 80:93-107

Harris RP (1996) Feeding ecology of Calanus. Ophelia 44 : $85-109$

Hay S (1995) Egg production and secondary production of common North Sea copepods: field estimates with regional and seasonal comparisons. ICES J Mar Sci 52: $315-327$

Hay SJ, Kiørboe T, Matthews A (1991) Zooplankton biomass and production in the North Sea during the autumn circulation experiment, October 1987-March 1988. Cont Shelf Res 11:1453-1476

Hirche HJ, Meyer U, Niehoff B (1997) Egg production of Calanus finmarchicus: effects of temperature, food and season. Mar Biol 127:609-620

Klein Breteler WCM, Fransz HG, Gonzalez SR (1982) Growth and development of four calanoid copepod species under experimental and natural conditions. Neth $J$ Sea Res 16 : $195-207$

Krause M, Dippner JW, Beil J (1995) A review of hydrographic controls on the distribution of zooplankton biomass and species in the North Sea with particular reference to a survey conducted in January-March 1987. Prog Oceanogr 35:81-152

Kuipers BR, Witte HJ (1999) Grazing impact of microzoo- 
plankton on different size classes of algae in the North Sea early spring and mid-summer. Mar Ecol Prog Ser (in press)

Lindley JA, John AWG, Robins DB (1997) Dry weight, carbon and nitrogen content of some calanoid copepods from the seas around southern Britain in winter. J Mar Biol Assoc UK 77:249-252

Matondka SGP, Bhat KL, Ansari ZA, Parulekar AH (1995) Elemental $(\mathrm{C}, \mathrm{H}, \mathrm{N})$ composition of zooplankton from the north Arabian Sea. Ind J Mar Sci 24:68-72

McLaren IA (1966) Predicting development rate of copepod eggs. Biol Bull 131:457-469

Mizdalski E (1988) Weight and length data of zooplankton in the Weddell Sea in austral spring 1986 (ANT V/3). Rep Polar Res 55:1-72

Nakamura Y. Turner JT (1997) Predation and respiration by the small cyclopoid copepod Oithona similis: how important is feeding on ciliates and heterotrophic flagellates? J Plankton Res 19:1275-1288

Nassogne A (1972) Etudes préliminaires sur le rôle du zooplancton dans la constitution et le transfert de la matière organique au sein de la chaine alimentaire marine en mer Ligure. Thesis, Univ of Amsterdam

Nielsen IG, Sabatini M (1996) The role of cyclopoid copepods Oithona spp. in North Sea plankton communities. Mar Ecol Prog Ser 139:79-93

Nielsen TG, Lokkegaard B, Richardson K, Pedersen FB, Hansen L (1993) Structure of plankton communities in the Dogger Bank area (North Sea) during a stratified situation. Mar Ecol Prog Ser 95:115-131

Ohman MD, Runge JA (1994) Sustained fecundity when phytoplanktor resources are in short supply--omnivory by Calanus finmarchicus in the Gulf of St-Lawrence. Limnol Oceanogr 39:21-36

Omori $\mathrm{M}$ (1978) Some factors affecting on dry weight, organic weight and concentrations of carbon and nitrogen in freshly prepared and in preserved zooplankton. Int Rev Ges Hydrobiol 63:261-269

Paffenhöfer GA (1976) On the biology of Appendicularia of the southeastern North Sea. In: Persoone G, Jaspers E (eds) Population dynamics of marine organisms in relation with nutrient cycling in shallow waters. Proc 10th Eur Mar Biol Symp. Ostend, Belgium, 17-23 September. Universa Press, Watteren, p 437-457

Peterson WT (1988) Rates of egg production by the copepod Calanus marshallae in the laboratory and in the sea off Oregon, U.S.A. Mar Ecol Prog Ser 47:229-237

Planque B, Fromentin JM (1996) Calanus and environment in the eastern North Atlantic. 1. Spatial and temporal patterns of C. finmarchicus and C. helgolandicus. Mar Ecol Prog Ser 134:101-109

Planque B, Hays GC, Ibanez F, Gamble JC (1997) Large scale

Editorial responsibility: Otto Kinne (Editor), Oldendorf/Luhe, Germany spatial variations in the seasonal abundance of Calanus finmarchicus. Deep-Sea Res I 44:315-326

Plourde S, Runge JA (1993) Reproduction of the planktonic copepod Calanus finmarchicus in the lower St. Lawrence Estuary: relation to the cycle of phytoplankton production and evidence for a Calanus pump. Mar Ecol Prog Ser 102: $217-227$

Riegman R, Noordeloos AAM (1998) Size-fractionated uptake of nitrogenous nutrients and carbon by phytoplankton in the North Sea during summer 1994. Mar Ecol Prog Ser 173:95-106

Riegman R, Kuipers BR, Noordeloos A, Witte HJ (1993) Sizedifferential control of phytoplanton and the structure of plankton communities. Neth J Sea Res 31:255-265

Riegman R, Flameling IA, Noordeloos AAM (1998) Size-fractionated uptake of ammonium, nitrate and urea and phytoplankton growth in the North Sea during spring 1994. Mar Ecol Prog Ser 173:85-94

Runge JA, Plourde S (1996) Fecundity characteristics of Calanus finmarchicus in coastal waters of Eastern Canada. Ophelia 44:171-187

Sabatini M, Kiørboe T (1994) Egg production, growth and development of the cyclopoid copepod Oithona similis. J Plankton Res 16:1329-1351

Seip P, Ottema M (1981) De betekenis van predatie voor de dichtheidsatname van de calanoide copepoden in juni/juli in de Zuidelijke Bocht van de Noordzee. Neth Inst Sea Res Publ Ser 1981-3:1-66

Slagstad D, Tande KS (1996) The importance of seasonal vertical migration in across shelf transport of Calanus finmarchicus. Ophelia 44:189-205

Turrell WR (1992) New hypotheses concerning the circulation of the northern North Sea and its relation to North Sea fish stock recruitment. ICES J Mar Sci 49:107-123

Uye SI (1982) Length-weight relationships of important zooplankton from the Inland Sea of Japan. J Oceanogr Soc Jpn 38:149-158

Wiebe $\mathrm{PH}_{1}$ Boyd S, Cox JL (1975) Relationships between zooplankton displacement volume, wet weight, dry weight, and carbon. Fish Bull 73:777-787

Williams R, Lindley JA (1980) Plankton of the Fladen Ground during FLEX 76 III. Vertical distribution, population dynamics and production of Calanus finmarchicus (Crustacea: Copepoda). Mar Biol 60:47-56

Williams R, Robins DB (1982) Effects of preservation on wet weight, dry weight, nitrogen and carbon contents of Calanus helgolandicus (Crustacea: Copepoda). Mar Biol 71:271-281

Williams R, Lindley JA, Hunt HG, Collins NR (1993) Plankton community structure and geographical distribution in the North Sea. J Exp Mar Biol Ecol 172:141-156

Submitted: February 23, 1998; Accepted: September 16, 1998 Proofs received from author(s): November 30, 1998 